Article

\title{
Synthesis, characterization, and catalytic performance of bifunctional titanium silicalite-1
}

\author{
LI Hao a,b, LEI Qian a, ZHANG Xiaoming a,*, SUO Jishuan a \\ a Chengdu Institute of Organic Chemistry, Chinese Academy of Sciences, Chengdu 610041, Sichuan, China \\ ${ }^{\mathrm{b}}$ College of Chemistry and Environmental Engineering, Yangtze University, Jingzhou 434023, Hubei, China
}

A R T I C L E I N F O

Article history:

Received 31 January 2013

Accepted 27 March 2013

Published 20 July 2013

\section{Keywords:}

Titanium silicalite-1

Aluminium

Boron

Iron

Bifunctional catalyst

Ethylene

Selective oxidation

\begin{abstract}
A B S T R A C T
A series of bifunctional Ti-molecular sieves (M-TS-1, $\mathrm{M}=\mathrm{Al}$, B, or Fe) containing different trivalent ions $\left(\mathrm{Al}^{3+}, \mathrm{B}^{3+}\right.$, or $\left.\mathrm{Fe}^{3+}\right)$, with MFI topology, were synthesized using tetrapropylammonium bromide, silica sol, and $n$-butylamine as a template, base, and Si source, respectively. The simultaneous presence of Ti and trivalent ions in lattice positions provided catalysts with activity in both oxidation and acid-catalyzed reactions. The samples were characterized using X-ray diffraction, Fourier-transform infrared spectroscopy, ultraviolet-visible spectroscopy, $\mathrm{NH}_{3}$ temperature-programmed desorption, inductively coupled plasma atomic emission spectroscopy, and $\mathrm{N}_{2}$ adsorption-desorption isotherms. The results showed that the numbers and strength of acid sites of TS-1 were enhanced by the incorporation of trivalent ions. Using selective oxidation of ethylene as the probe reaction, the catalytic properties of M-TS-1 were investigated. The results showed that Al-TS- 1 and B-TS-1 had better catalytic properties; conversion and utilization of $\mathrm{H}_{2} \mathrm{O}_{2}$ reached $95 \%$ and $90 \%$, respectively, and the yield of ethylene glycol plus its monomethyl ether was greater than $10 \%$.
\end{abstract}

(C) 2013, Dalian Institute of Chemical Physics, Chinese Academy of Sciences. Published by Elsevier B.V. All rights reserved.

\section{Introduction}

Titanium silicalite-1 (TS-1) was first synthesized by Taramasso et al. [1] in 1983 and received extensive attention because it shows excellent performance in selective oxidation reactions with dilute $\mathrm{H}_{2} \mathrm{O}_{2}$ as the oxidant, requires mild reaction conditions, has high activity and selectivity, and is environmentally benign [2-4]. Recently, several studies of the synthesis of zeolites containing both $\mathrm{Ti}$ and a trivalent element $\left(\mathrm{Al}^{3+}, \mathrm{Ga}^{3+}, \mathrm{Fe}^{3+}\right.$, or $\left.\mathrm{B}^{3+}\right)$ in MFI structure have been reported [5-14]. The simultaneous presence of Ti and trivalent elements in lattice positions provides catalysts that are active in both oxidation and acid-catalyzed reactions. One class of methods for the preparation of bifunctional Ti silicalite-1 (M-TS-1) [5-10] is based on hydrothermal crystallization of a hydrogel obtained by basic hydrolysis of the respective precursors with aqueous tetrapropylammonium hydroxide (TPAOH). Bellussi et al. [5] have synthesized Al-TS-1, Ga-TS-1, and Fe-TS-1 using hydrothermal synthesis. The resulting materials exhibited high activity in the epoxidation of 1-butene, hydroxylation of phenol, and oligomerization of 1-octene, indicating that the acidity of the zeolite is enhanced by the incorporation of trivalent ions. Trong On et al. [6,9] have synthesized B-TS-1 by in-situ incorporation of $\mathrm{B}^{3+}$ and $\mathrm{Ti}^{4+}$ ions into the MFI structure during hydrothermal synthesis. The bifunctional catalyst effectively catalyzes the epoxidation of 1-hexene and 1-octene, followed by ring opening of the epoxide through hydrolysis and solvolysis reactions. Another class of methods for M-TS-1 preparation [11-14] is based on wetness impregnation of amorphous $\mathrm{M}_{2} \mathrm{O}_{3}-\mathrm{TiO}_{2}-\mathrm{SiO}_{2}(\mathrm{M}=\mathrm{Al}$ or $\mathrm{Fe}$ ) solids with $\mathrm{TPAOH}$ solution and

*Corresponding author. Tel: +86-28-85226215; Fax: +86-28-85223978; E-mail: xm.zhang@cioc.ac.cn DOI: 10.1016/S1872-2067(12)60589-0 | http://www.sciencedirect.com/science/journal/18722067 | Chin. J. Catal., Vol. 34, No. 7, July 2013 
subsequent crystallization under autogenous pressure. Ovejero et al. [13] synthesized Al-TS-1 by wetness impregnation of amorphous $\mathrm{Al}_{2} \mathrm{O}_{3}-\mathrm{TiO}_{2}-\mathrm{SiO}_{2}$ solids. Al-TS- 1 showed high activity for $n$-hexane oxidation and methanol/tert-butyl alcohol etherification, suggesting that the catalyst is active in both oxidation and acid-catalyzed reactions. However, the two classes of methods for M-TS-1 preparation mentioned above use expensive TPAOH as the template, and the synthesis requires stringent conditions (alkali-free TPAOH solutions).

Recently, we successfully prepared Al-TS-1 using tetrapropylammonium bromide (TPABr), silica sol, and $n$-butylamine (NBA) as a template, silica source, and base, respectively [15]. Both the number of acid sites in TS- 1 and the site acidity were enhanced by the incorporation of $\mathrm{Al}^{3+}$. Al-TS- 1 exhibited high catalytic activity in the selective oxidation of ethylene to ethylene glycol (EG) using a mixed solvent consisting of methanol and water. In this work, the synthesis, characterization, and catalytic properties of M-TS-1 (M = Al, B, or Fe) in the selective oxidation of ethylene were further studied.

\section{Experimental}

\subsection{Preparation of $M-T S-1$}

M-TS-1 was prepared using a previously reported method [15] from colloidal silica (30\%, Qingdao Hengshengda Chemical Co., Ltd), tetrabutyl orthotitanate (TBOT, AR, Chengdu Kelong Chemical Reagent Factory ), $\mathrm{Al}\left(\mathrm{NO}_{3}\right)_{3} \cdot 9 \mathrm{H}_{2} \mathrm{O}$ (99.0\%, Guangdong Guanghua Chemical Factory Co., Ltd), $\mathrm{H}_{3} \mathrm{BO}_{3}$ (99.5\%, Shantou Guanghua Chemical Factory), and $\mathrm{Fe}\left(\mathrm{NO}_{3}\right)_{3} \cdot 9 \mathrm{H}_{2} \mathrm{O}$ (98.5\%, Guangdong Guanghua Chemical Factory Co., Ltd) as the sources of $\mathrm{Si}, \mathrm{Ti}, \mathrm{Al}, \mathrm{B}$, and $\mathrm{Fe}$ respectively. $\mathrm{TPABr}$ (99.0\%, Jintan Southwest Chemical Institute) was used as the template, and NBA (AR, Chengdu Kelong Chemical Reagent Factory) was used as the base.

\subsection{1. $B-T S-1$}

In a typical synthesis, $12.8 \mathrm{~g}$ of TPABr and $92.7 \mathrm{~g}$ of silica sol (30\%) were dissolved in $142 \mathrm{~g}$ of deionized water; the resulting mixture was denoted by solution 1 . Also, $4.61 \mathrm{~g}$ of TBOT were dissolved in $6.4 \mathrm{~g}$ of aqueous $\mathrm{H}_{2} \mathrm{O}_{2}$ solution (30\%), and $20.7 \mathrm{~g}$ of NBA were added (solution 2). Then solution 2 was slowly added to solution 1 under vigorous stirring, followed by dropwise addition of $0.082 \mathrm{~g}$ of $\mathrm{H}_{3} \mathrm{BO}_{3}$ dissolved in $50 \mathrm{~g}$ of deionized water. The molar composition was $\mathrm{SiO}_{2}: \mathrm{BB}_{2} \mathrm{O}_{3}: 0.03 \mathrm{TiO}_{2}: 0.6 \mathrm{NBA}$ : $0.1 \mathrm{TPABr}: 30 \mathrm{H}_{2} \mathrm{O}$, where $1 / x=200-800$. Finally, $1.2 \mathrm{~g}$ of TS-1 powder were added as seeds. After stirring at $333 \mathrm{~K}$ for $2 \mathrm{~h}$ to accelerate hydrolysis and evaporate the alcohol, the gel was transferred to a Teflon-lined autoclave and heated at $448 \mathrm{~K}$ under autogenous pressure for $72 \mathrm{~h}$. Finally, the solid product was recovered by centrifugation, washed with distilled water, dried overnight at $373 \mathrm{~K}$, and calcined at $823 \mathrm{~K}$ for $5 \mathrm{~h}$. A reference TS-1 zeolite was also prepared using the synthesis procedure described above but omitting the $\mathrm{H}_{3} \mathrm{BO}_{3}$ addition step.

\subsection{2. $F e-T S-1$}

The Fe-TS-1 molecular sieve was synthesized using a gel with composition $\mathrm{SiO}_{2}: \mathrm{Fe}_{2} \mathrm{O}_{3}: 0.03 \mathrm{TiO}_{2}$ :0.6NBA:0.1TPABr: $30 \mathrm{H}_{2} \mathrm{O}$, where $1 / x=300-1000$. A typical preparation was similar to that of B-TS-1, the only difference being that a solution containing $0.519 \mathrm{~g}$ of $\mathrm{Fe}\left(\mathrm{NO}_{3}\right)_{3} \cdot 9 \mathrm{H}_{2} \mathrm{O}$ in $50 \mathrm{~g}$ of deionized water instead of $\mathrm{H}_{3} \mathrm{BO}_{3}$ solution was added dropwise after addition of solution 2 to solution 1 .

\subsubsection{Al-TS-1}

The Al-TS-1 catalyst was synthesized using a gel with composition $\quad \mathrm{SiO}_{2}: 0.002 \mathrm{Al}_{2} \mathrm{O}_{3}: 0.03 \mathrm{TiO}_{2}: 0.6 \mathrm{NBA}: 0.1 \mathrm{TPABr}: 30 \mathrm{H}_{2} \mathrm{O}$. The preparation was similar to that of $\mathrm{B}-\mathrm{TS}-1$, the only difference being that a solution of $0.689 \mathrm{~g}$ of $\mathrm{Al}\left(\mathrm{NO}_{3}\right)_{3} \cdot 9 \mathrm{H}_{2} \mathrm{O}$ in $50 \mathrm{~g}$ of deionized water instead of $\mathrm{H}_{3} \mathrm{BO}_{3}$ solution was added dropwise to solution 1 before solution 2 was added.

\subsection{Characterization of M-TS-1}

The samples were characterized using X-ray diffraction (XRD; Philips X'PERT, Cu $K_{\alpha}$ radiation), Fourier-transform infrared (FT-IR) spectroscopy (Nicolet MX-1E 560, KBr pellet technique), and ultraviolet-visible (UV-Vis) spectroscopy (TU-1091 spectrometer, $\mathrm{BaSO}_{4}$ as reference). The chemical compositions of the samples were determined using inductively coupled plasma atomic emission spectroscopy (ICP-AES; Perkin-Elmer Optima DV 2000). Nitrogen adsorption-desorption isotherms were obtained on a Micromeritics ASAP 2420 instrument. Samples were degassed at $473 \mathrm{~K}$ under vacuum overnight prior to the measurements. $\mathrm{NH}_{3}$ temperature-programmed desorption ( $\mathrm{NH}_{3}$-TPD) measurements were performed in a fixed-bed reactor connected to a thermal conductivity detector (GC 2000II). The sample (about $100 \mathrm{mg}$ ) was initially activated at $673 \mathrm{~K}$ for $1 \mathrm{~h}$ in an ultrahigh-purity Ar flow (25 ml/min). It was then cooled to $373 \mathrm{~K}$ and pure $\mathrm{NH}_{3}(20$ $\mathrm{ml} / \mathrm{min}$ ) was adsorbed for $1.5 \mathrm{~h}$. The sample was then flushed with pure $\operatorname{Ar}\left(25 \mathrm{ml} / \mathrm{min}\right.$ ) for $1 \mathrm{~h}$ at $373 \mathrm{~K}$. The $\mathrm{NH}_{3}$-TPD curves of the samples were obtained by increasing the temperature from 373 to $873 \mathrm{~K}$ at a ramp rate of $10 \mathrm{~K} / \mathrm{min}$ under a pure $\mathrm{Ar}$ flow of $25 \mathrm{ml} / \mathrm{min}$.

\subsection{Catalysis tests for selective oxidation of ethylene}

The selective oxidation of ethylene with dilute $\mathrm{H}_{2} \mathrm{O}_{2}$ was carried out at $333 \mathrm{~K}$ in a stainless-steel autoclave reactor. In a typical run, $4.0 \mathrm{~g}$ of calcined catalyst, $40.0 \mathrm{ml}$ of about $30 \%$ $\mathrm{H}_{2} \mathrm{O}_{2}, 50 \mathrm{ml}$ of water, and $150 \mathrm{ml}$ of methanol were fed into the stainless-steel autoclave reactor. Then ethylene was charged at a constant pressure (0.7 MPa). After heating the mixture at 333 $\mathrm{K}$ under agitation for a certain period, the residual $\mathrm{H}_{2} \mathrm{O}_{2}$ was checked by iodometric titration. The reaction products were analyzed using a gas chromatograph (Shanghai Techcomp Instrument Co., Ltd, GC 7890F chromatograph, SE-54, capillary column $15 \mathrm{~m} \times 0.25 \mathrm{~mm}$ ) equipped with a flame ionization detector using acetonitrile as the internal standard. The GC analysis conditions were as follows: the column box temperature was $343 \mathrm{~K}$, the gasification chamber temperature was 493 $\mathrm{K}$, and the detector temperature was $493 \mathrm{~K}$. EG and its monomethyl ether (MME) were the main products. The reac- 
tion results are reported using the following criteria:

$$
\begin{gathered}
X\left(\mathrm{H}_{2} \mathrm{O}_{2}\right)=\left[n_{0}\left(\mathrm{H}_{2} \mathrm{O}_{2}\right)-n\left(\mathrm{H}_{2} \mathrm{O}_{2}\right)\right] / n_{0}\left(\mathrm{H}_{2} \mathrm{O}_{2}\right) \times 100 \% \\
U\left(\mathrm{H}_{2} \mathrm{O}_{2}\right)=[n(\mathrm{EG})+n(\mathrm{MME})] /\left[n_{0}\left(\mathrm{H}_{2} \mathrm{O}_{2}\right) \times X\left(\mathrm{H}_{2} \mathrm{O}_{2}\right)\right] \times 100 \% \\
S(\mathrm{EG})=n(\mathrm{EG}) /[n(\mathrm{EG})+n(\mathrm{MME})] \times 100 \% \\
S(\mathrm{MME})=n(\mathrm{MME}) /[n(\mathrm{EG})+n(\mathrm{MME})] \times 100 \%
\end{gathered}
$$

where $X\left(\mathrm{H}_{2} \mathrm{O}_{2}\right), U\left(\mathrm{H}_{2} \mathrm{O}_{2}\right), S(\mathrm{EG})$, and $S(\mathrm{MME})$ are the $\mathrm{H}_{2} \mathrm{O}_{2}$ conversion, the utilization of $\mathrm{H}_{2} \mathrm{O}_{2}$, the selectivity for $\mathrm{EG}$, and the selectivity for MME, respectively. The moles of EG and MME are represented by $n(\mathrm{EG})$ and $n(\mathrm{MME})$, respectively; $n_{0}\left(\mathrm{H}_{2} \mathrm{O}_{2}\right)$ and $n\left(\mathrm{H}_{2} \mathrm{O}_{2}\right)$ are the initial and final molar contents of $\mathrm{H}_{2} \mathrm{O}_{2}$, respectively.

\section{Results and discussion}

\subsection{Characterization results of $M-T S-1$}

Table 1 lists the physicochemical properties of the TS- 1 and M-TS- 1 catalysts. The TS- 1 contains a trace amount of Al from the silica sol used as the silicon source. Both $\mathrm{Al}$ and Ti were incorporated into the TS-1 framework $[16,17]$. The trivalent elements and Ti contents of the TS- 1 and M-TS- 1 are lower than those of the initial gel, indicating that not all the $\mathrm{Al}^{3+}, \mathrm{B}^{3+}$, $\mathrm{Fe}^{3+}$, and $\mathrm{Ti}^{4+}$ are involved in the crystallization process $[5,7,11]$. The Brunauer-Emmett-Teller (BET) surface areas and micropore volumes of the TS-1 zeolite change little upon incorporation of trivalent ions, indicating that the pore structure is well preserved.

Figure 1 shows the XRD patterns of the TS- 1 and M-TS-1. The samples show the characteristics of MFI topology without an impure phase, indicating that the incorporation of trivalent

\begin{tabular}{|c|c|c|c|c|c|c|c|}
\hline \multirow{2}{*}{ Sample } & \multicolumn{2}{|c|}{ Gel } & \multicolumn{2}{|c|}{ Zeolite } & \multirow{2}{*}{$\begin{array}{c}A_{\text {BET }} \\
\left(\mathrm{m}^{2} / \mathrm{g}\right) \\
\end{array}$} & \multirow{2}{*}{$\begin{array}{l}V_{\text {micropore }} \\
\left(\mathrm{cm}^{3} / \mathrm{g}\right)\end{array}$} & \multirow{2}{*}{$\begin{array}{c}\mathrm{NH}_{3} \\
(\mathrm{mmol} / \mathrm{g})\end{array}$} \\
\hline & $\mathrm{Si} / \mathrm{Ti}$ & $\mathrm{Si} / \mathrm{M}$ & $\mathrm{Si} / \mathrm{Ti}$ & $\mathrm{Si} / \mathrm{M}$ & & & \\
\hline TS-1 & 33.3 & $\infty$ & 36.5 & 393.1 & 399.0 & 0.11 & 0.13 \\
\hline Al-TS-1 & 33.3 & 252.0 & 42.1 & 434.5 & 395.9 & 0.11 & 0.21 \\
\hline B-TS-1 & 33.3 & 350.0 & 50.9 & 364.0 & 389.1 & 0.11 & 0.17 \\
\hline Fe-TS-1 & 33.3 & 360.0 & 51.1 & 375.4 & 390.3 & 0.11 & 0.19 \\
\hline
\end{tabular}
elements does not destroy the zeolite structure.

Table 1

Physicochemical properties of TS-1and M-TS-1 zeolites.

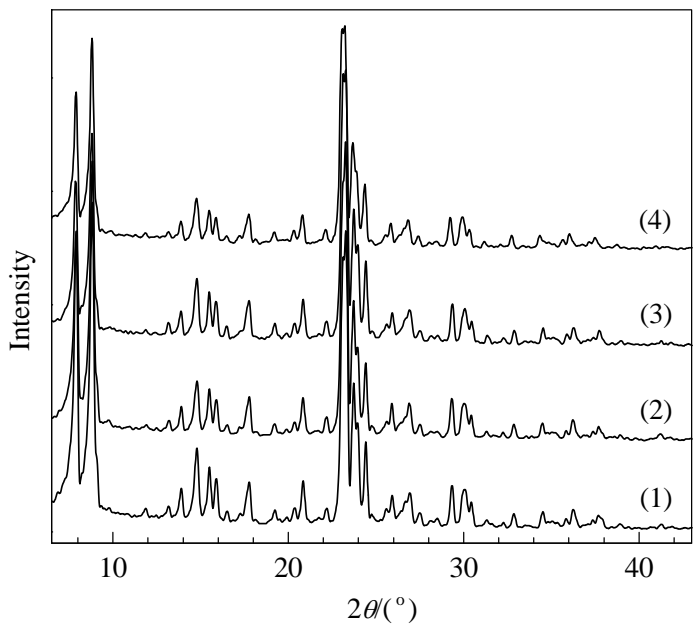

Fig. 1. XRD patterns of TS-1 and M-TS- 1 . (1) TS-1; (2) Al-TS-1 (Si/Al = 252); (3) B-TS-1 (Si/B = 350); (4) Fe-TS-1 ( $\mathrm{Si} / \mathrm{Fe}=360)$.

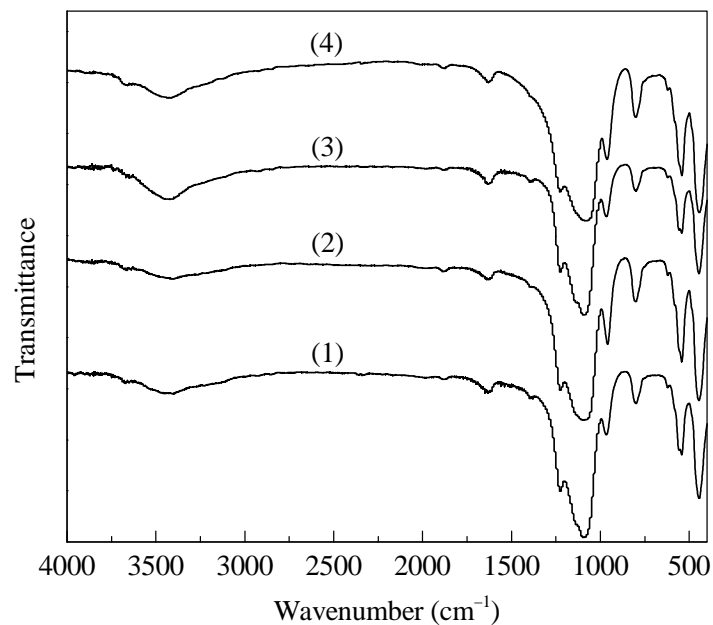

Fig. 2. FT-IR spectra of TS-1 and M-TS-1. (1) TS-1; (2) Al-TS-1 (Si/Al = 252); (3) B-TS-1 (Si/B = 350); (4) Fe-TS-1 ( $\mathrm{Si} / \mathrm{Fe}=360$ ).

Figure 2 shows FT-IR spectra of TS- 1 and M-TS-1. The samples show a characteristic peak at about $960 \mathrm{~cm}^{-1}$, attributed to the $\mathrm{Si}-\mathrm{O}$ vibration in the $\mathrm{O}_{3} \mathrm{Si}-\mathrm{O}-\mathrm{Ti}$ structure, which indicates that Ti was incorporated into the zeolite framework [18].

Figure 3 shows the UV-Vis spectra of TS- 1 and M-TS- 1 . The samples exhibit a main absorption band at about $220 \mathrm{~nm}$, attributed to isolated Ti(IV) species, and another band at 270-280 $\mathrm{nm}$, attributed to $\mathrm{Ti}^{4+}$ ions octahedrally coordinated with two $\mathrm{H}_{2} \mathrm{O}$ molecules in the coordination sphere, or small hydrated oligomeric $\mathrm{TiO}_{x}$ species [19]. There is also a weak peak at about $330 \mathrm{~nm}$ from extra-framework Ti oxide [20], indicating that some extra-framework Ti species are systematically generated in the presence of trivalent ions [7]. These results are in good agreement with the ICP-AES analysis (Table 1).

The acidity of the TS- 1 and M-TS- 1 catalysts was studied using $\mathrm{NH}_{3}$-TPD, and the profiles are shown in Fig. 4. An $\mathrm{NH}_{3}$ desorption peak at about $444.1 \mathrm{~K}$ was observed for TS-1, and its $\mathrm{NH}_{3}$ adsorption capacity was $0.13 \mathrm{mmol} / \mathrm{g}$ (Table 1), indicating that TS-1 prepared in this study had weak acid sites $[16,17]$. When additional trivalent ions $\left(\mathrm{Al}^{3+}, \mathrm{B}^{3+}\right.$, or $\left.\mathrm{Fe}^{3+}\right)$ were

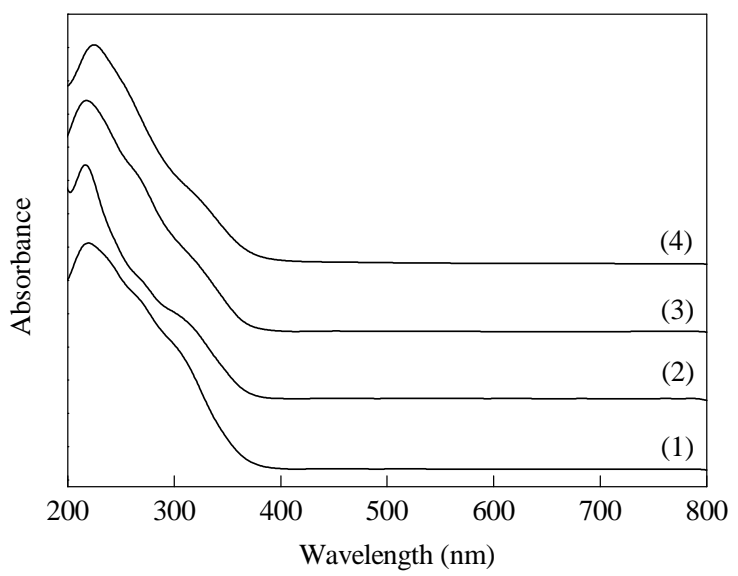

Fig. 3. UV-Vis spectra of TS-1 and M-TS-1. (1) TS-1; (2) Al-TS-1 (Si/Al = 252); (3) B-TS-1 ( $\mathrm{Si} / \mathrm{B}=350$ ); (4) Fe-TS-1 ( $\mathrm{Si} / \mathrm{Fe}=360$ ). 


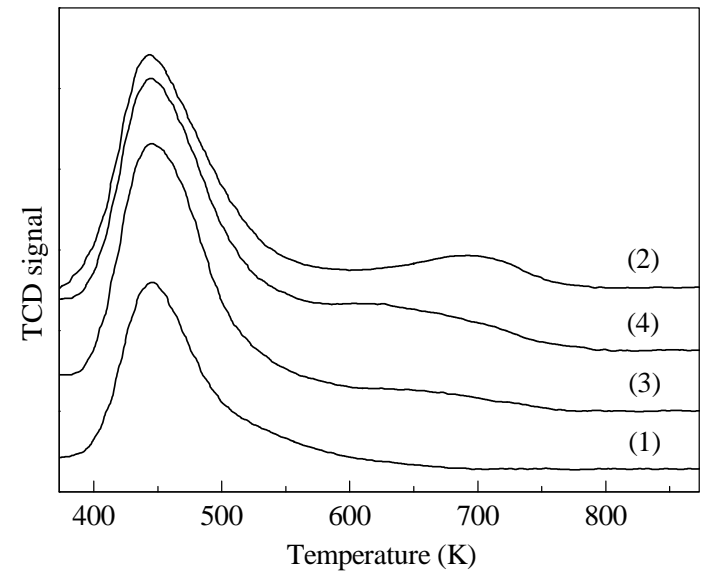

Fig. 4. $\mathrm{NH}_{3}$-TPD profiles of TS-1 and M-TS-1. (1) TS-1; (2) Al-TS-1 (Si/Al = 252); (3) B-TS-1 ( $\mathrm{Si} / \mathrm{B}=350)$; (4) Fe-TS-1 ( $\mathrm{Si} / \mathrm{Fe}=360$ ).

introduced, the intensity of the peak at about $444.1 \mathrm{~K}$ increased significantly, and a small broad desorption peak (at $677.4 \mathrm{~K}$ for B-TS-1 and Fe-TS-1, and at 701.9 K for Al-TS-1) appeared. The order of the acid strengths was TS-1 < B-TS-1 < Fe-TS-1 < Al-TS-1 (Table 1), which is in consistent with the results for the FT-IR spectra of adsorbed pyridine [7]. These results indicated that the amounts and strength of the acid sites of TS- 1 were both enhanced by introducing trivalent ions during preparation.

It is widely accepted that substitution by trivalent ions such

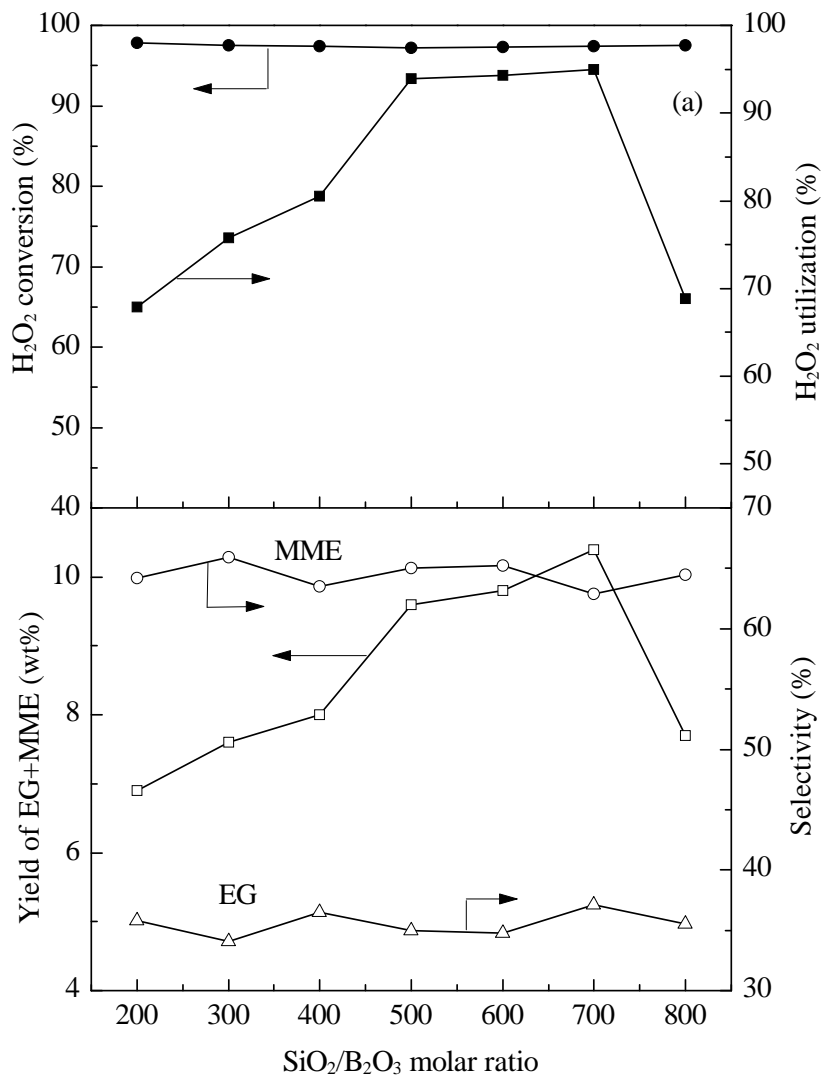

as $\mathrm{Al}^{3+}$ and $\mathrm{B}^{3+}$ or transition-metal ions such as $\mathrm{Fe}^{3+}$ can occur in many minerals. In contrast to most silicates, isomorphous substitution in a zeolite can only take place at tetrahedral sites [6]. It was reported that most of the trivalent ions $\left(\mathrm{Al}^{3+}, \mathrm{B}^{3+}\right.$, and $\mathrm{Fe}^{3+}$ ) were essentially incorporated into the TS-1 framework in tetrahedral environments [5,7-13].

\subsection{Catalytic properties of $M-T S-1$}

Figure 5(a) shows the results of selective oxidation of ethylene with dilute $\mathrm{H}_{2} \mathrm{O}_{2}$ over B-TS- 1 with different $\mathrm{B}$ contents. When the $\mathrm{SiO}_{2} / \mathrm{B}_{2} \mathrm{O}_{3}$ molar ratio decreased from 800 to 700 , the $\mathrm{H}_{2} \mathrm{O}_{2}$ conversion and EG and MME selectivity changed little, but the $\mathrm{H}_{2} \mathrm{O}_{2}$ utilization and the yield of EG plus MME increased significantly. When the $\mathrm{SiO}_{2} / \mathrm{B}_{2} \mathrm{O}_{3}$ molar ratio decreased from 700 to 500 , the $\mathrm{H}_{2} \mathrm{O}_{2}$ conversion and $\mathrm{EG}$ and MME selectivity changed little, and the $\mathrm{H}_{2} \mathrm{O}_{2}$ utilization and the yield of EG plus MME decreased slightly. On further decreasing the $\mathrm{SiO}_{2} / \mathrm{B}_{2} \mathrm{O}_{3}$ to 200 , the $\mathrm{H}_{2} \mathrm{O}_{2}$ conversion and EG and MME selectivity changed little, but the $\mathrm{H}_{2} \mathrm{O}_{2}$ utilization and the yield of EG plus MME decreased significantly. These results indicate that when an excess of $\mathrm{B}$ is introduced, the degree of $\mathrm{H}_{2} \mathrm{O}_{2}$ decomposition is enhanced $[8,9]$. B-TS- $1\left(\mathrm{SiO}_{2} / \mathrm{B}_{2} \mathrm{O}_{3}=350\right)$ should therefore be an appropriate catalyst.

Figure 5(b) shows the results of selective oxidation of ethylene with dilute $\mathrm{H}_{2} \mathrm{O}_{2}$ over Fe-TS-1 with different Fe contents. When the $\mathrm{SiO}_{2} / \mathrm{Fe}_{2} \mathrm{O}_{3}$ molar ratio decreased from 1000 to 720 , the $\mathrm{H}_{2} \mathrm{O}_{2}$ conversion and EG and MME selectivity changed little,

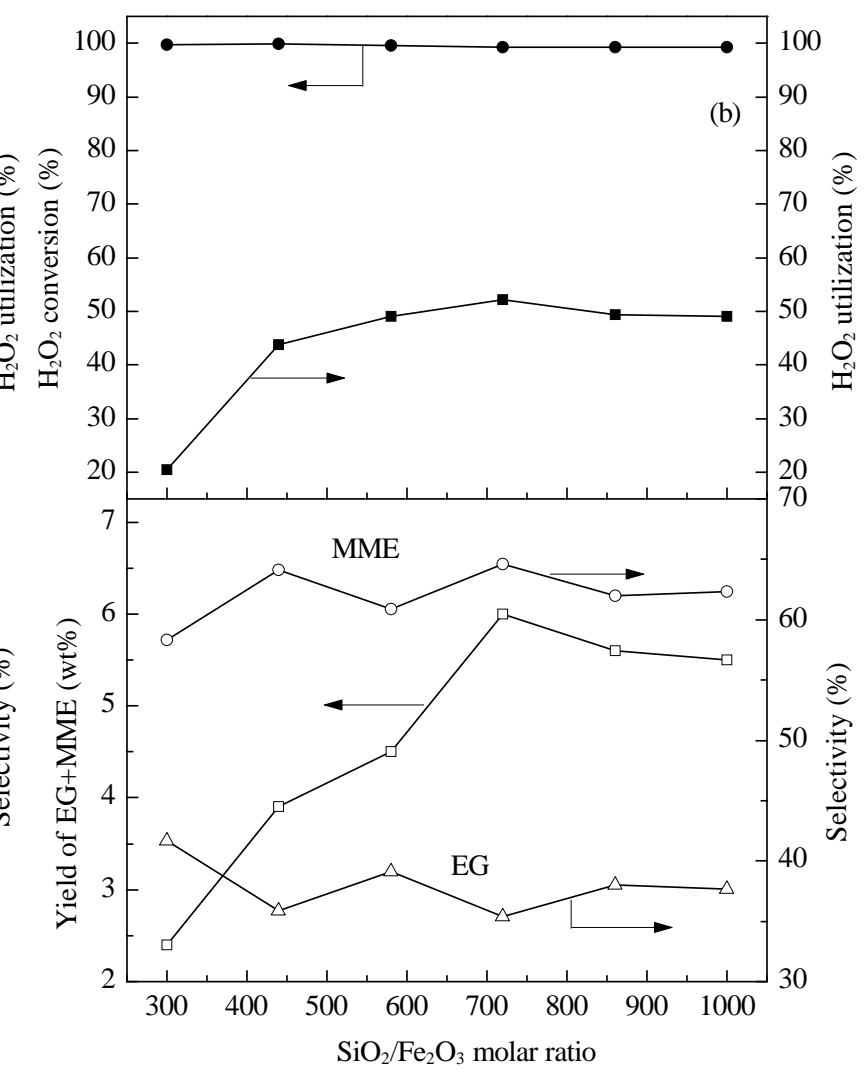

Fig. 5. Selective oxidation of ethylene with dilute $\mathrm{H}_{2} \mathrm{O}_{2}$ over B-TS-1 with different $\mathrm{B}$ contents (a) and over Fe-TS-1 with different Fe contents (b). Reaction conditions: ethylene pressure $0.7 \mathrm{MPa}, \mathrm{H}_{2} \mathrm{O}_{2} 1.7 \mathrm{~mol} / \mathrm{L}$, catalyst $17.2 \mathrm{~g} / \mathrm{L}$, methanol/water (molar ratio 0.8 ) mixed solvent, $333 \mathrm{~K}, 8 \mathrm{~h}$. 
but the $\mathrm{H}_{2} \mathrm{O}_{2}$ utilization and the yield of EG plus MME increased significantly. On further decreasing the $\mathrm{SiO}_{2} / \mathrm{Fe}_{2} \mathrm{O}_{3}$ molar ratio, the $\mathrm{H}_{2} \mathrm{O}_{2}$ conversion and EG and MME selectivity changed little, but the $\mathrm{H}_{2} \mathrm{O}_{2}$ utilization and yield of EG plus MME began to decrease. When the $\mathrm{SiO}_{2} / \mathrm{Fe}_{2} \mathrm{O}_{3}$ was 720 , $\mathrm{Fe}-\mathrm{TS}-1$ gave a relatively good catalytic performance.

In the selective oxidation of ethylene with dilute $\mathrm{H}_{2} \mathrm{O}_{2}$ over Al-TS-1 ( $\mathrm{Si} / \mathrm{Al}=252$ ) using the mixed solvent methanol and water, the conversion and utilization of $\mathrm{H}_{2} \mathrm{O}_{2}$ were $98.3 \%$ and $92.3 \%$, respectively, and the yield of EG plus MME was $10.1 \%$. Investigation of the catalytic performance of $\mathrm{Al}-\mathrm{TS}-1(\mathrm{Si} / \mathrm{Al}=$ 252) and B-TS-1 ( $\mathrm{Si} / \mathrm{B}=350$ ) showed that they had high catalytic activity and selectivity. The conversion and utilization of $\mathrm{H}_{2} \mathrm{O}_{2}$ reached $95 \%$ and $90 \%$, respectively, and the yield of EG plus MME was above $10 \%$. However, Fe-TS-1 (Si/Fe = 360) exhibited poor catalytic selectivity because of its strong ability to decompose $\mathrm{H}_{2} \mathrm{O}_{2}$ [5].

\subsection{Reaction mechanism}

To study the relation between $\mathrm{H}_{2} \mathrm{O}_{2}$ decomposition and selective oxidation of ethylene, a blank experiment was conducted. The conversion of $\mathrm{H}_{2} \mathrm{O}_{2}$ was $14.6 \%$, and $\mathrm{H}_{2} \mathrm{O}_{2}$ utilization and the yield of EG plus MME were zero. Comparing the results of the blank experiment with those using M-TS-1, it could be concluded that $\mathrm{H}_{2} \mathrm{O}_{2}$ decomposition and selective oxidation of ethylene are competing reactions. In the cases of Al-TS- 1 and B-TS-1, the effect of trivalent ions on $\mathrm{H}_{2} \mathrm{O}_{2}$ decomposition could be neglected, but this was not consistent with results reported in the literature $[5,8,9]$.

Figure 6(a) shows the effect of reaction time on the selective oxidation of ethylene over Al-TS-1. It can be seen that the yield of EG plus MME and the conversion and utilization of $\mathrm{H}_{2} \mathrm{O}_{2}$ increased linearly with increasing reaction time (from 1 to $4 \mathrm{~h}$ ). On further prolonging the reaction time, the yield of EG plus MME and the conversion and utilization of $\mathrm{H}_{2} \mathrm{O}_{2}$ changed little. The selectivity for MME and EG remained constant with increasing reaction time (Fig. 6(a)). Moreover, one can clearly see that the MME selectivity was about twice that for EG for all reaction time. An appropriate reaction time was therefore $4 \mathrm{~h}$.

Figure 6(b) shows the effect of reaction time on the selective oxidation of ethylene over B-TS-1. On prolonging the reaction time from 1 to $4 \mathrm{~h}$, the yield of EG plus MME and the conversion and utilization of $\mathrm{H}_{2} \mathrm{O}_{2}$ increased linearly. When the reaction time was increased to $7 \mathrm{~h}$, the yield of EG plus MME and the conversion and utilization of $\mathrm{H}_{2} \mathrm{O}_{2}$ increased slightly. When the reaction time was prolonged further, the $\mathrm{H}_{2} \mathrm{O}_{2}$ conversion changed little, but $\mathrm{H}_{2} \mathrm{O}_{2}$ utilization and the yield of EG plus MME began to decrease. The selectivity for MME and EG was constant for all reaction time (Fig. 6(b)). Moreover, one can clearly see that the MME selectivity was about twice that for EG for all reaction time; this was similar to the case for Al-TS-1. The appropriate reaction time was therefore $7 \mathrm{~h}$, which is longer than that for Al-TS-1. The discrepancy between the optimum reaction time might be caused by the different physicochemical properties of the trivalent ions [7].
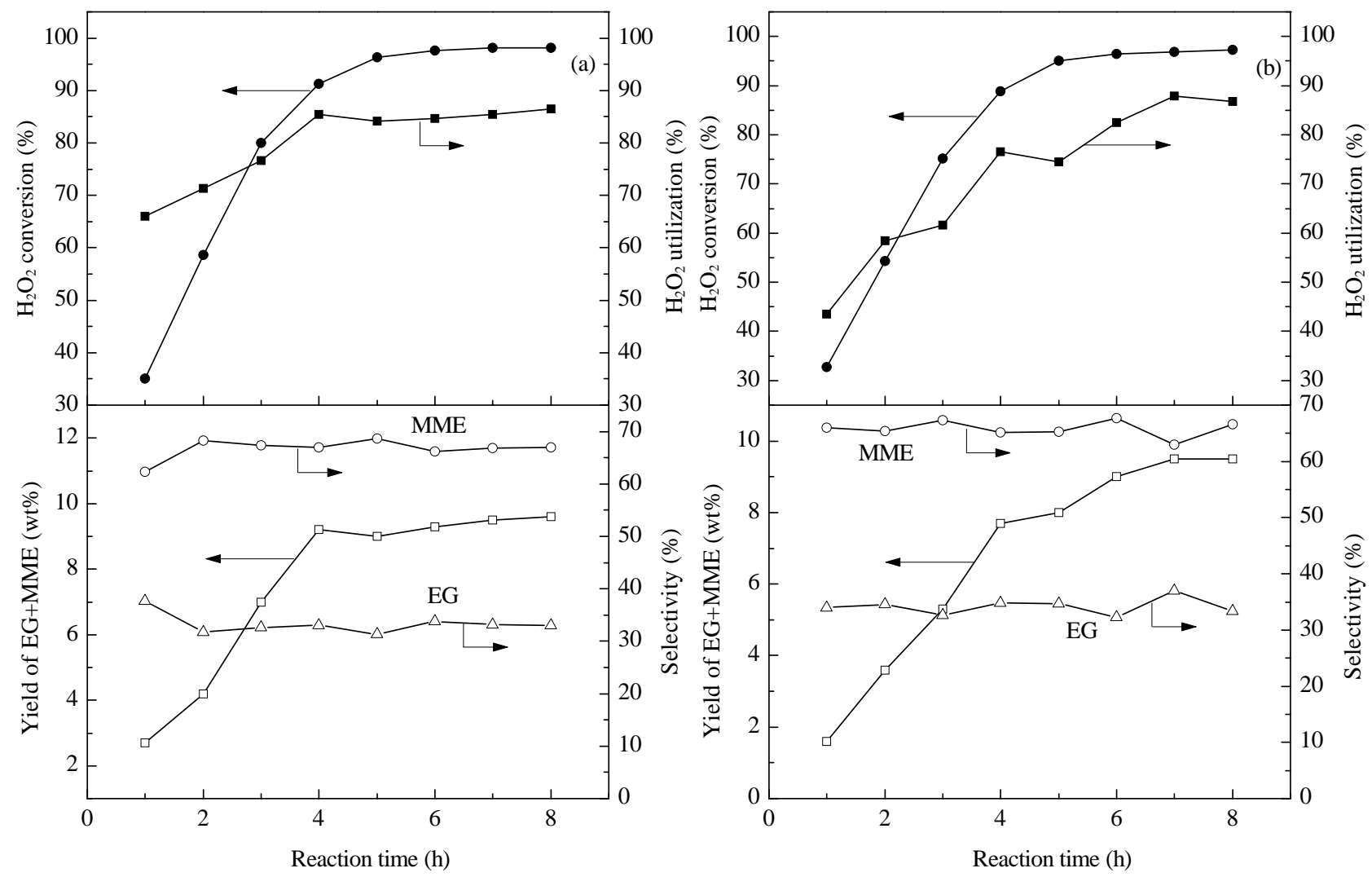

Fig. 6. Effect of reaction time on selective oxidation of ethylene over Al-TS-1 ( $\mathrm{Si} / \mathrm{Al}=252)(\mathrm{a})$ and $\mathrm{B}-\mathrm{TS}-1(\mathrm{Si} / \mathrm{B}=350)(\mathrm{b})$. Reaction conditions were the same as those in Fig. 5. 


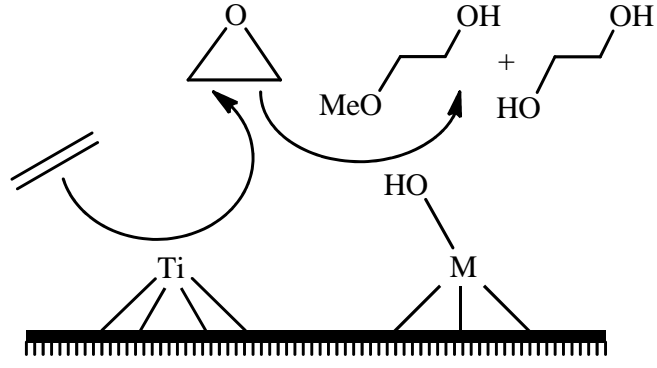

Oxidative active site

Acidic active site
Scheme 1. Proposed model of M-TS-1 $(\mathrm{M}=\mathrm{Al}$ or $\mathrm{B})$ as a bifunctional catalyst for ethylene epoxidation and subsequent ring-opening process.

In the ethylene epoxidation and subsequent ring-opening process, if the hydrolysis and methanolysis of ethylene epoxide are slow reactions, then oxirane would be one of the final products; however, we did not detect oxirane using GC. The solvolysis of oxirane was therefore fast, and the ethylene epoxidation step was the slow and rate-determining step. As a result of the hydrophobic character of TS-1, methanol approaches Ti sites more readily than water does, leading to the formation of more stable five-membered-ring intermediates [21]. In addition, because of the stronger nucleophilicity of the alcohol compared with water [22], methanolysis of oxirane was easier than hydrolysis. The MME selectivity was therefore higher than that for EG for all reaction time. Because the epoxide immediately reacted with active acid sites in $\mathrm{M}(\mathrm{Al}$ or $\mathrm{B})$ to solvolyze oxirane, the trivalent ions $\left(\mathrm{Al}^{3+}\right.$ or $\left.\mathrm{B}^{3+}\right)$ incorporated into the framework of TS-1 would effectively be located close to Ti active sites. On the basis of these results, a model of the bifunctional oxidative and acidic catalytic system for consecutive reactions of ethylene to MME and EG is proposed and is shown in Scheme 1 [15].

\section{Conclusions}

M-TS-1 was prepared by introducing a trivalent ion into the TPABr-NBA system. M-TS-1 was active in both oxidation and acid-catalyzed reactions. Characterization using various techniques showed that trivalent ions were incorporated into the TS-1 framework, and the MFI structure was well preserved in M-TS-1. The introduction of trivalent ions into the framework of the TS-1 zeolite resulted in increases in the numbers and strength of the acid sites; the order of the acid strength was TS-1 < B-TS-1 < Fe-TS-1 < Al-TS-1. The oxidative and acid-catalyzed activity was adjusted by introducing different concentrations of trivalent elements into the zeolite framework. Al-TS-1 (Si/Al = 252) and B-TS-1 ( Si/B = 350) exhibited higher catalytic activity in the selective oxidation of ethylene; the conversion and utilization of $\mathrm{H}_{2} \mathrm{O}_{2}$ reached $95 \%$ and $90 \%$, respectively, and the yield of EG plus MME reached $10 \%$. These values are comparable to those achieved in current industrial processes for EG production. Finally, a model of M-TS-1 as a bifunctional catalyst for ethylene epoxidation and a subsequent ring-opening process was proposed.

\section{References}

[1] Taramasso M, Perego G, Notari B. US Patent 4410501.1983

[2] Ratnasamy P, Srinivas D, Knözinger H. Adv Catal, 2004, 48: 1

[3] Yang J X, Yao M K, Zhao S, Liu Y M, Wu P, He M Y. Chin J Catal (杨俊 霞, 姚明恺, 赵松, 刘月明, 吴鹏, 何鸣元. 催化学报), 2010, 31: 95

[4] Deng X J, Shen L, Zhang Sh, Liu Y M. Chin J Catal (邓秀娟, 申璐, 张 硕, 刘月明. 催化学报), 2011, 32: 1550

[5] Bellusi G, Carati A, Clerici M G, Esposito A. Stud Surf Sci Catal, 1991, 63: 421

[6] Trong On D, Kaliaguine S, Bonneviot L.J Catal, 1995, 157: 235

[7] Trong On D, Nguyen S V, Hulea V, Dumitriu E, Kaliaguine S. Microporous Mesoporous Mater, 2003, 57: 169

[8] Trong On D, Kapoor M P, Bonneviot L, Kaliaguine S, Gabelica Z. J Chem Soc, Faraday Trans, 1996, 92: 1031

[9] Kapoor M P, Trong On D, Gallot J E, Kaliaguine S. Catal Lett, 1997, 43: 127

[10] Pirutko L V, Uriarte A K, Chernyavsky V S, Kharitonov A S, Panov G I. Microporous Mesoporous Mater, 2001, 48: 345

[11] Ovejero G, van Grieken R, Uguina M A, Serrano D P, Melero J A. Catal Lett, 1996, 41: 69

[12] Melero J A, van Grieken R, Serrano D P, Espada J J. J Mater Chem, 2001, 11: 1519

[13] Ovejero G, van Grieken R, Uguina M A, Serrano D P, Melero J A. J Mater Chem, 1998, 8: 2269

[14] Ovejero G, Sotelo J L, Martínez F, Melero J A, Gordo L. Ind Eng Chem Res, 2001, 40: 3921

[15] Li H, Lei Q, Zhang X M, Suo J S. Catal Commun, 2009, 10: 1936

[16] Guo X W, Wang X S, Liu M, Li G, Chen Y Y, Xiu J H, Zhuang J Q, Zhang W P, Bao X H. Catal Lett, 2002, 81: 125

\section{Graphical Abstract}

Chin. J. Catal., 2013, 34: 1363-1372 doi: 10.1016/S1872-2067(12)60589-0

\section{Synthesis, characterization, and catalytic performance of bifunctional titanium silicalite-1}

LI Hao, LEI Qian, ZHANG Xiaoming*, SUO Jishuan

Chengdu Institute of Organic Chemistry, Chinese Academy of Sciences;

Yangtze University

The coincorporation of Ti and a trivalent ion into the MFI-type zeolite was studied. The acidity of TS-1 was enhanced by introducing trivalent ions. M-TS-1 showed higher activity in the selective oxidation of ethylene.

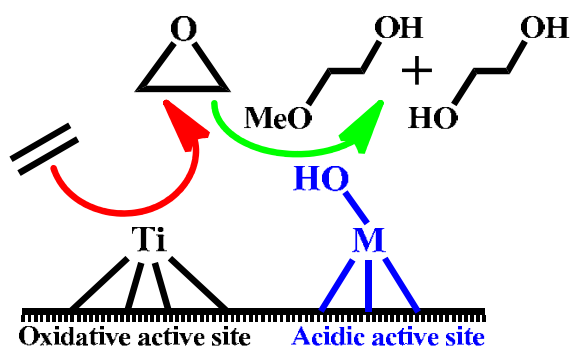


[17] Li G, Wang X Sh, Yan H Sh, Liu M, Liu Y H, Chen Y Y. Chin J Catal (李 钢, 王祥生, 问海生, 刘民, 刘毅慧, 陈永英. 催化学报), 2001，22: 465

[18] Scarano D, Zecchina A, Bordiga S, Geobaldo F, Spoto G, Petrini G, Leofanti G, Padovan M, Tozzola G. J Chem Soc, Faraday Trans, 1993, 89: 4123
[19] Wang X S, Guo X W, Li G. Catal Today, 2002, 74: 65

[20] Boccuti M R, Rao K M, Zecchina A, Leofanti G, Petrini G. Stud Surf Sci Catal, 1989, 48: 133

[21] Fan W B, Wu P, Tatsumi T. J Catal, 2008, 256: 62

[22] Liu X Y, Yin D L, Zhu H Y, Shen G. Chin J Catal (刘绪艳, 尹笃林, 朱 华元, 沈刚. 催化学报), 2010, 31: 72

\title{
双功能钛硅分子篮的合成、表征及催化性能
}

\author{
李 影 ${ }^{\mathrm{a}, \mathrm{b}}$, 雷 骞 ${ }^{\mathrm{a}}$, 张小明 $\mathrm{a}^{\text {, }}$, 索继栓 ${ }^{\mathrm{a}}$ \\ a 中国科学院成都有机化学研究所, 四川成都610041 \\ ${ }^{b}$ 长江大学化学与环境工程学院, 湖北荆州 434023
}

\begin{abstract}
摘要: 以四丙基溴化铵为模板剂, 硅溶胶为硅源, 正丁胺为碱源, 采用水热合成的方法, 将三价离子 $\left(\mathrm{Al}^{3+}, \mathrm{B}^{3+}\right.$ 或 $\left.\mathrm{Fe}^{3+}\right)$ 和 $\mathrm{Ti}^{4+}$ 同时 引入到MFI型分子篮的骨架, 得到同时具有氧化和酸催化活性的双功能钛硅分子篎M-TS-1 (M = Al, B或Fe). 通过X射线粉末衍 射、傅里叶变换红外光谱、紫外-可见漫反射光谱、氨程序升温脱附、电感耦合等离子体原子发射光谱和 $\mathrm{N}_{2}$ 吸附-脱附等温线手 段对样品进行了表征. 结果表明, 三价离子的引入, 提高了TS-1的酸强度和酸量. 采用乙烯选择氧化为探针反应考察了M-TS-1 的催化性能. 结果表明, Al-TS-1和B-TS-1在乙烯环氧化及后续的开环溶剂解反应中表现出较高的催化性能, $\mathrm{H}_{2} \mathrm{O}_{2}$ 的转化率在 $95 \%$ 以上, $\mathrm{H}_{2} \mathrm{O}_{2}$ 的利用率大于 $90 \%$ ，乙二醇和乙二醇单甲醚的总收率可达 $10 \%$ 以.
\end{abstract}

关键词: 钣硅分子篮; 铝; 硼; 铁; 双功能催化剂; 乙烯; 选择氧化

收稿日期: 2013-01-31. 接受日期: 2013-03-27. 出版日期: 2013-07-20.

*通讯联系人. 电话: (028)85226215; 传真: (028)85223978; 电子信箱: xm.zhang@cioc.ac.cn

本文的英文电子版由Elsevier出版社在ScienceDirect上出版(http://www.sciencedirect.com/science/journal/18722067).

\section{1. 前言}

钛硅分子篮TS-1自 Taramasso等 ${ }^{[1]}$ 首次报道合成以 来, 由于其优异的选择氧化催化性能及其催化的反应具 有对环境污染轻、反应条件温和等优点而备受关注 ${ }^{[24]}$. 近年来, 研究者 ${ }^{[514]}$ 尝试在分子篮的合成过程中引入其 它三价离子 $\left(\mathrm{Al}^{3+}, \mathrm{Ga}^{3+}, \mathrm{Fe}^{3+}\right.$ 或 $\mathrm{B}^{3+}$ 等 $)$ 修饰其催化性能. $\mathrm{Ti}^{4+}$ 和三价离子同时进入分子篮的骨架，使分子篮不但 对氧化反应有催化活性，而且对酸催化反应也有催化活 性. 双功能钛硅分子篎的一类制备方法 ${ }^{[5 ~ 10]}$ 是利用原料 在四丙基氢氧化铵(TPAOH)水溶液中分别水解，制得水 凝胶, 然后对该凝胶进行水热晶化. Bellussi等 ${ }^{[5]}$ 采用水 热合成法制备了 Al-TS-1, Ga-TS-1和Fe-TS-1, 它们在1丁烯液相环氧化、苯酚羟基化和1-辛烯低聚反应中均表 现出较好的催化活性, 说明三价金属的引入增加了 TS-1 分子篮的酸性. Trong On等 ${ }^{[6,9]}$ 采用水热合成法将 $\mathrm{B}^{3+}$ 和 $\mathrm{Ti}^{4+}$ 直接引入分子篮骨架, 合成出具有氧化和酸催化活 性的B-TS-1, 其在1-己烯和1-辛烯的选择氧化反应中促 进了环氧化物的开环水解和溶剂解. 双功能钛硅分子笁 的另一类制备方法 ${ }^{[11 ~ 14]}$ 是以非晶固体 $\mathrm{M}_{2} \mathrm{O}_{3}-\mathrm{TiO}_{2}-\mathrm{SiO}_{2}$ $(\mathrm{M}=\mathrm{Al}$ 或 $\mathrm{Fe})$ 为原料, 用 $\mathrm{TPAOH}$ 溶液浸渍, 然后水热晶 化. Ovejero等 ${ }^{[13]}$ 以非晶的 $\mathrm{Al}_{2} \mathrm{O}_{3}-\mathrm{TiO}_{2}-\mathrm{SiO}_{2}$ 为原料, 通过 浸渍法合成出 Al-TS-1, 其在正己烷氧化和甲醇与叔丁
醇的醚化反应中均表现出较高的催化活性, 说明 Al-TS-1同时具有氧化和酸催化性能. 但是, 上述两类 方法都需要采用价格昂贵的TPAOH为原料, 而且操作 条件苛刻.

最近，我们采用四丙基溴化铵(TPABr)为模板剂, 硅溶胶为硅源, 正丁胺为碱源, 成功地制备出 $\mathrm{Al}-\mathrm{TS}-1^{[15]} \cdot \mathrm{Al}^{3+}$ 的引入增大了 $\mathrm{TS}-1$ 的酸强度和酸量. 采 用甲醇和水混合溶剂, Al-TS-1在乙烯选择氧化制乙二 醇的反应中表现出良好的催化性能. 本文进一步研究了 双功能铁硅分子篮Al-TS-1, B-TS-1和Fe-TS-1的制备、表 征及其在乙烯选择氧化反应中的催化性能.

\section{2. 实验部分}

\section{1. 分子篮的合成}

参照文献[15]制备双功能钛硅分子篮M-TS-1. 采用 硅溶胶 $\left(w\left(\mathrm{SiO}_{2}\right)=30 \%\right.$, 青岛恒盛达化工有限公司 $)$ 为硅 源, 钛酸正丁酯(TBOT, 分析纯, 成都市科龙化工试剂 厂)为钛源, 四丙基溴化铵(99.0\%, 金坛市西南化工研究 所)为模板剂, 正丁胺(NBA, 分析纯, 成都市科龙化工 试剂厂)为碱源, 九水合硝酸铝(99.0\%, 广东光华化学厂 有限公司)为铝源, 嗍酸( $99.5 \%$, 汕头市光华化学厂)为 硼源, 九水合硝酸铁(98.5\%, 广东光华化学厂有限公司) 为铁源. 


\subsubsection{B-TS-1的合成}

首先, 将 $12.8 \mathrm{~g}$ TPABr和 $92.7 \mathrm{~g}$ 硅溶胶溶解于 $142 \mathrm{~g}$ 去离子水中, 得到溶液 1 ; 另外配制 TBOT (4.61 g) 的 $\mathrm{H}_{2} \mathrm{O}_{2}$ (30\%, $6.4 \mathrm{~g}$ )络合水溶液, 加入 $20.7 \mathrm{~g} \mathrm{NBA}$, 得到溶 液2. 在剧烈搅拌下, 将溶液2加入到溶液1中, 然后滴加 一定浓度的硼酸水溶液, 所得溶液的物料比为 $\mathrm{SiO}_{2}$ : $x \mathrm{~B}_{2} \mathrm{O}_{3}: 0.03 \mathrm{TiO}_{2}: 0.6 \mathrm{NBA}: 0.1 \mathrm{TPABr}: 30 \mathrm{H}_{2} \mathrm{O}$, 其 中 $1 / x=$ 200 800. 最后, 加入 1.2 g TS-1晶种, 加热至333 K蒸醇, 转移入高压釜(聚四氟乙烯为祄里), $448 \mathrm{~K}$ 下晶化 $3 \mathrm{~d}$. 将 得到的晶化产物过滤, 水洗至 $\mathrm{pH}=7$, 在 $373 \mathrm{~K}$ 下过夜干 燥, 最后在马弗炉中 $823 \mathrm{~K}$ 下焙烧 $5 \mathrm{~h}$, 即得B-TS-1分子 篎. 作为对照, 按照上述合成步骤制备TS-1分子篮, 只 是不添加嗍酸.

\subsubsection{Fe-TS-1的合成}

按照摩尔比配料 $\mathrm{SiO}_{2}: \mathrm{xF}_{2} \mathrm{O}_{3}: 0.03 \mathrm{TiO}_{2}: 0.6 \mathrm{NBA}$ : 0.1TPABr: $30 \mathrm{H}_{2} \mathrm{O}(1 / x=300 \sim 1000)$ 合成Fe-TS-1. 其合成 操作与B-TS-1类似, 将一定浓度的嗍酸水溶液换成一定 浓度的硝酸铁水溶液即可.

\subsubsection{Al-TS-1的合成}

按照摩尔比配料 $\mathrm{SiO}_{2}: 0.002 \mathrm{Al}_{2} \mathrm{O}_{3}: 0.03 \mathrm{TiO}_{2}$ : 0.6NBA:0.1TPABr: $30 \mathrm{H}_{2} \mathrm{O}$ 合成Al-TS-1. 其合成操作与 B-TS-1类似, 只不过将一定浓度的硝酸铝水溶液逐滴加 入到溶液1中.

\section{2. 分子篮的表征}

$\mathrm{X}$-射线粉末衍射 (XRD) 测试在荷兰帕纳科公司 $\mathrm{X}^{\prime}$ pert pro MPD型X射线衍射仪上进行, $\mathrm{Cu} K_{\alpha}$ 辐射. 傅里叶 变换红外光谱(FT-IR)分析在美国Nicolet MX-1E 560型 傅立叶变换红外光谱仪上进行, $\mathrm{KBr}$ 压片. 紫外-可见漫 反射光谱(UV-Vis)光谱分析在TU-1091型光谱仪上进行, $\mathrm{BaSO}_{4}$ 作为参比物, 测试范围190 800 nm. 电感耦合等 离子体原子发射光谱 (ICP-AES) 分析在美国 Perkin-Elmer公司Optima DV 2000型光谱仪上进行. 在 Micromeritics ASAP 2420型气体吸附测试仪上测定样品 的比表面积和微孔体积, 以氮气为吸附质. 氨程序升温 脱附( $\left.\mathrm{NH}_{3}-\mathrm{TPD}\right)$ 在一个连有气相色谱仪(GC 2000II型)的 固定床上进行. 将 $100 \mathrm{mg}$ 样品在高纯氩气流 $(25 \mathrm{ml} / \mathrm{min}$ ) 中 $673 \mathrm{~K}$ 下活化 $1 \mathrm{~h}$, 降至 $373 \mathrm{~K}$, 然后在此温度下吸附纯 氨 $(20 \mathrm{ml} / \mathrm{min}) 1.5 \mathrm{~h}$, 再用高纯氩气流 $(25 \mathrm{ml} / \mathrm{min}$ )在此温 度下吹扫 $1 \mathrm{~h}$. 最后, 样品在高纯氩气流 $(25 \mathrm{ml} / \mathrm{min})$ 中以 $10 \mathrm{~K} / \mathrm{min}$ 的速率从 $373 \mathrm{~K}$ 程序升温到 $873 \mathrm{~K}$.

\section{3. 乙烯选择氧化反应}

乙烯选择氧化反应在一个 $500 \mathrm{ml}$ 不锈钢高压釜内进
行. 典型的操作如下: 首先, 将 $4.0 \mathrm{~g}$ 催化剂、 $40 \mathrm{ml} \mathrm{H}_{2} \mathrm{O}_{2}$ $(w=30 \%) 、 50 \mathrm{ml}$ 蒸馏水和 $150 \mathrm{ml}$ 甲醇装入高压釜, 然后 加热至 $333 \mathrm{~K}$, 通入乙烯, 使反应釜中的压力达到 0.7 $\mathrm{MPa}$, 反应8 h. 乙二醇(EG)和乙二醇单甲醚(MME)为主 要产物. 反应液中 $\mathrm{H}_{2} \mathrm{O}_{2}$ 的含量采用碘量法来分析, 产物 组成由上海天美科学仪器有限公司GC 7890F型气相色 谱仪(SE-54毛细管柱, $15 \mathrm{~m} \times 0.25 \mathrm{~mm}$ ) 分析, 乙腈为内 标. 色谱条件如下: 柱箱温度 $343 \mathrm{~K}$, 汽化室温度 $493 \mathrm{~K}$, 检测器温度 $493 \mathrm{~K}$. 催化剂的催化性能评定指标有:

$$
\begin{aligned}
& X\left(\mathrm{H}_{2} \mathrm{O}_{2}\right)= {\left[n_{0}\left(\mathrm{H}_{2} \mathrm{O}_{2}\right)-n\left(\mathrm{H}_{2} \mathrm{O}_{2}\right)\right] / n_{0}\left(\mathrm{H}_{2} \mathrm{O}_{2}\right) \times 100 \% } \\
& U\left(\mathrm{H}_{2} \mathrm{O}_{2}\right)=[n(\mathrm{EG})+n(\mathrm{MME})] / \\
& {\left[n_{0}\left(\mathrm{H}_{2} \mathrm{O}_{2}\right) \times X\left(\mathrm{H}_{2} \mathrm{O}_{2}\right)\right] \times 100 \% } \\
& S(\mathrm{EG})=n(\mathrm{EG}) /[n(\mathrm{EG})+n(\mathrm{MME})] \times 100 \% \\
& S(\mathrm{MME})=n(\mathrm{MME}) /[n(\mathrm{EG})+n(\mathrm{MME})] \times 100 \%
\end{aligned}
$$

式中 $X, U$ 和 $S$ 分别表示 $\mathrm{H}_{2} \mathrm{O}_{2}$ 转化率、 $\mathrm{H}_{2} \mathrm{O}_{2}$ 利用率和 $E G$ 和 MME的选择性; $n_{0}\left(\mathrm{H}_{2} \mathrm{O}_{2}\right)$ 和 $n\left(\mathrm{H}_{2} \mathrm{O}_{2}\right)$ 分别表示反应开始和 结束时 $\mathrm{H}_{2} \mathrm{O}_{2}$ 的量; $n(E G)$ 和 $n(M M E)$ 分别表示乙二醇和乙 二醇单甲醚的量.

\section{3. 结果与讨论}

\section{1. 双功能钛硅分子篮M-TS-1的表征结果}

表1给出了TS-1和M-TS-1催化剂的化学组成和物理 特征. 可以明显地看出, TS-1中含有少量的Al. 来源于 原料硅溶胶中所含的杂质 $\mathrm{Al}$, 并且 $\mathrm{Al}$ 和 $\mathrm{Ti}$ 同时进入了 TS-1分子篮的骨架 ${ }^{[16,17]}$. Al-TS-1, B-TS-1和Fe-TS-1中的 $\mathrm{Ti}$ 和三价元素的含量都比初始凝胶中的含量低. 这表明 并不是所有的 $\mathrm{Ti}^{4+}, \mathrm{Al}^{3+}, \mathrm{B}^{3+}$ 和 $\mathrm{Fe}^{3+}$ 都参与了晶化过程而 进入分子篮的骨架 ${ }^{[5,7,11]}$. 与TS-1相比, M-TS-1的BET比 表面积和微孔体积变化不大, 说明M-TS-1的孔结构保 持良好.

图1是TS-1和M-TS-1催化剂的XRD谱. 可以看出, TS-1, Al-TS-1, B-TS-1和Fe-TS-1都具有典型的MFI拓扑 结构特征衍射峰, 为分子笁纯相, 说明掺杂 $\mathrm{Al}^{3+}, \mathrm{B}^{3+}$ 或 $\mathrm{Fe}^{3+}$ 没有破坏TS-1的结构.

图2是TS-1和M-TS-1催化剂的红外光谱. 可以看出, TS-1, Al-TS-1, B-TS-1和Fe-TS-1在960 $\mathrm{cm}^{-1}$ 处都有一个 明显的吸收峰. 一般认为, 此峰归属于骨架 Ti-O-Si的 伸缩振动, 说明 $\mathrm{Ti}^{4+}$ 进入了分子篮的骨架 ${ }^{[18]}$.

图3是TS-1和M-TS-1催化剂的UV-Vis谱. 可以看 出, TS-1, Al-TS-1, B-TS-1和Fe-TS-1在220 nm附近都有 一个强的吸收峰, 说明分子篎骨架中含有孤立的四配位 的钛; 其在270 280 nm附近的弱吸收峰归属于分子篮 
中 $\mathrm{Ti}^{4+}$ 离子与两个 $\mathrm{H}_{2} \mathrm{O}$ 分子配位形成八面体或者部分缩 聚的 $\mathrm{TiO}_{x}$ 物种 $^{[19]}$. TS-1, Al-TS-1, B-TS-1和Fe-TS-1在330 $\mathrm{nm}$ 附近呈现出一个弱的吸收峰, 说明分子篎中可能含 有少量的非骨架锐钛矿型 $\mathrm{TiO}_{2}{ }^{[20]}$. 这是由于在晶化过程 中三价离子与 $\mathrm{Ti}^{4+}$ 竞争, 导致一部分 $\mathrm{Ti}^{4+}$ 没有进入分子 篎的骨架, 而以非骨架的形态存在 ${ }^{[7]}$. 该结果与表 1 的元 素分析结果一致.

图4是TS-1和M-TS-1催化剂的 $\mathrm{NH}_{3}$-TPD谱. 可以看 出, TS-1在 $444.1 \mathrm{~K}$ 附近有一个明显的 $\mathrm{NH}_{3}$ 脱附峰, 对应 的氨气的吸附能力为 $0.13 \mathrm{mmol} / \mathrm{g}$ (见表 1 ). 这表明采用 TPABr-NBA体系合成的 TS-1具有弱酸性, 主要归因于 原料硅溶胶中所携带的微量杂质铝 ${ }^{[16,17]}$. 掺杂 $\mathrm{Al}^{3+}, \mathrm{B}^{3+}$ 或 $\mathrm{Fe}^{3+}$ 后, $444.1 \mathrm{~K}$ 附近的氨气脱附峰的强度明显增大. 另外, B-TS-1和Fe-TS-1在677.4 K左右出现一个较弱的 氨气脱附峰, 而Al-TS-1则在701.9 K左右出现一个较强 的氨气脱附峰. TS-1和M-TS-1酸性强弱的顺序为TS-1< B-TS-1 < Fe-TS-1 < Al-TS-1 (见表 1). 该结果与 Trong On等 ${ }^{[7]}$ 采用吡啶吸附红外光谱的研究结果基本一致. 以 上结果表明, 三价离子的引入增大了 TS-1的酸强度和酸 量.

$\mathrm{Al}^{3+}, \mathrm{B}^{3+}$ 或过渡金属离子如 $\mathrm{Fe}^{3+}$ 可以在很多矿物中 取代硅. 与硅质岩不同的是, 沸石中的同晶取代只能在 四配位的晶格点上进行 ${ }^{[6]}$. 对于 Al-TS-1, Fe-TS-1 和 B-TS-1, 大部分三价离子以四配位的状态嵌入在分子篎 的骨架上, 这已经被很多研究者的报道所证实 ${ }^{[5,7 \sim 13]}$.

\section{2. 双功能钛硅分子篮M-TS-1的催化性能}

图5(a)给出了B-TS-1催化乙烯选择氧化的反应结 果. 当 $\mathrm{SiO}_{2} / \mathrm{B}_{2} \mathrm{O}_{3}$ 摩尔比从 800 减小到 700 时, $\mathrm{H}_{2} \mathrm{O}_{2}$ 基本完 全转化, $\mathrm{H}_{2} \mathrm{O}_{2}$ 的利用率及EG和MME的总收率迅速增加, 而EG和MME的选择性变化不大. 当 $\mathrm{SiO}_{2} / \mathrm{B}_{2} \mathrm{O}_{3}$ 摩尔比减 小到 500 时, $\mathrm{H}_{2} \mathrm{O}_{2}$ 的转化率和利用率变化不大, EG 和 MME的总收率开始降低, 而EG和MME的选择性变化 不大. 进一步减小 $\mathrm{SiO}_{2} / \mathrm{B}_{2} \mathrm{O}_{3}$ 摩尔比, $\mathrm{H}_{2} \mathrm{O}_{2}$ 的利用率及 EG和MME的总收率迅速降低, 而 $\mathrm{H}_{2} \mathrm{O}_{2}$ 的转化率及EG 和MME的选择性变化不大. 这些结果说明, 过量 $\mathrm{B}^{3+}$ 的 引入会导致 $\mathrm{H}_{2} \mathrm{O}_{2}$ 无效分解程度的增强 ${ }^{[8,9]}$. 因此, B-TS-1 $\left(\mathrm{SiO}_{2} / \mathrm{B}_{2} \mathrm{O}_{3}=700\right)$ 是一个合适的催化剂.

图5(b)给出了 Fe-TS-1催化乙烯选择氧化的反应结 果. 当 $\mathrm{SiO}_{2} / \mathrm{Fe}_{2} \mathrm{O}_{3}$ 摩尔比从 1000 减小到 720 时, $\mathrm{H}_{2} \mathrm{O}_{2}$ 基本 完全转化, $\mathrm{H}_{2} \mathrm{O}_{2}$ 的利用率及EG和MME的总收率增加, 而 $\mathrm{EG}$ 和 MME 的选择性基本不变. 进一步减小 $\mathrm{SiO}_{2} / \mathrm{Fe}_{2} \mathrm{O}_{3}$ 摩尔比, $\mathrm{H}_{2} \mathrm{O}_{2}$ 的转化率变化不大, $\mathrm{H}_{2} \mathrm{O}_{2}$ 的利用
率及EG和MME的总收率开始降低, 而EG和MME的选 择性基本不变. 因此, 当 $\mathrm{SiO}_{2} / \mathrm{Fe}_{2} \mathrm{O}_{3}=720$ 时催化剂具有 相对较好的催化性能.

在乙烯的选择氧化反应中, 采用 Al-TS-1 $(\mathrm{Si} / \mathrm{Al}=$ 252)为催化剂, 其 $\mathrm{H}_{2} \mathrm{O}_{2}$ 的转化率和利用率分别为 $98.3 \%$ 和 $92.3 \%$, EG 和 MME的总收率为 $10.1 \%$. 对比 Al-TS-1, B-TS-1和Fe-TS-1的催化性能可以发现, Al-TS-1 (Si/Al = 252) 和 B-TS-1 ( $\mathrm{Si} / \mathrm{B}=350)$ 的催化活性和选择性较高, 其 $\mathrm{H}_{2} \mathrm{O}_{2}$ 利用率达 $90 \%$ 以上, 转化率达 $95 \%$ 以上, EG和 MME 的总收率可达 $10 \%$ 以上. 而对于 Fe-TS-1 (Si/Fe = 360 ), EG和MME的总收率只有 $6.0 \%$, 虽然 $\mathrm{H}_{2} \mathrm{O}_{2}$ 基本完全 转化, 但是 $\mathrm{H}_{2} \mathrm{O}_{2}$ 的利用率只有 $52.1 \%$, 催化选择性较差. 这可能是由于Fe-TS-1具有较强的 $\mathrm{H}_{2} \mathrm{O}_{2}$ 分解能力所致 ${ }^{[5]}$.

\section{3. 反应机理}

为了研究 $\mathrm{H}_{2} \mathrm{O}_{2}$ 热分解和乙烯选择氧化反应之间的 关系, 我们进行了空白实验. 结果表明, $\mathrm{H}_{2} \mathrm{O}_{2}$ 转化率为 $14.6 \%$, 而 $\mathrm{H}_{2} \mathrm{O}_{2}$ 利用率及EG和MME的总收率都为 0 . 与 上述Al-TS-1, Fe-TS-1和B-TS-1的催化结果对比可知, $\mathrm{H}_{2} \mathrm{O}_{2}$ 的分解和乙烯选择氧化反应之间是竞争关系. 对 于Al-TS-1和B-TS- $1, \mathrm{H}_{2} \mathrm{O}_{2}$ 的分解可以忽略, 这与文献 $[5,8,9]$ 的报道不一致.

图6(a)是反应时间对Al-TS-1催化乙烯选择氧化反 应的影响. 当反应时间从 $1 \mathrm{~h}$ 增加到 $4 \mathrm{~h}$ 时, $\mathrm{H}_{2} \mathrm{O}_{2}$ 的转化 率、 $\mathrm{H}_{2} \mathrm{O}_{2}$ 的利用率及EG和MME的总收率线性增加; 进 一步延长反应时间, $\mathrm{H}_{2} \mathrm{O}_{2}$ 的转化率、 $\mathrm{H}_{2} \mathrm{O}_{2}$ 的利用率及EG 和MME的总收率变化不大; 整个过程中 MME和EG选 择性变化不大, 且 $M M E / E G$ 的摩尔比一直保持在 2 左右. 这是一个很有趣的现象. 因此, 最佳的反应时间为 $4 \mathrm{~h}$.

图6(b)是反应时间对B-TS-1催化乙烯选择氧化反应 的影响. 当反应时间从 $1 \mathrm{~h}$ 增加到 $4 h$ 时, $\mathrm{H}_{2} \mathrm{O}_{2}$ 的转化率、 $\mathrm{H}_{2} \mathrm{O}_{2}$ 的利用率及EG和MME的总收率迅速增加; 继续延 长反应时间到7 h, $\mathrm{H}_{2} \mathrm{O}_{2}$ 的转化率、 $\mathrm{H}_{2} \mathrm{O}_{2}$ 的利用率及EG 和MME的总收率缓慢增加; 进一步延长反应时间, $\mathrm{H}_{2} \mathrm{O}_{2}$ 的转化率变化不大, 而 $\mathrm{H}_{2} \mathrm{O}_{2}$ 的利用率及EG和MME的总 收率开始降低. 整个过程中MME和EG选择性变化不大, 并且MME/EG的摩尔比一直保持在 2左右. 这与Al-TS-1 上的现象相同. 因此, 最佳的反应时间为 $7 \mathrm{~h}$. 与 Al-TS-1相比, B-TS-1催化乙烯选择氧化的反应时间要 长一些, 这可能是由三价离子各自的物理化学性质所决 定的 ${ }^{[7]}$.

在乙烯环氧化及后续的开环溶剂解过程中, 如果溶 剂解是慢反应, 在产物中应该有环氧乙烷(EO)被检测出 
来, 但是气相色谱并没有检测出EO. 因此, 溶剂解是快 反应，环氧化反应是慢反应，即决速步骤. 由于TS-1具 有疏水性，与水相比，甲醇可以很容易地与 Ti配位，形 成更加稳定的五元环中间体 ${ }^{[21]}$. 此外，由于醇的亲核性 比水强 ${ }^{[22],} \mathrm{EO}$ 的开环醇解更加容易进行. 因此, 在反应 过程中MME的选择性一直比EG高. 由于生成的EO立即 和三价离子所形成的酸性位作用发生开环溶剂解反应, 进入TS-1分子篎骨架的三价离子 $\left(\mathrm{Al}^{3+}\right.$ 或 $\left.\mathrm{B}^{3+}\right)$ 应该距离氧 化活性位点 $\mathrm{Ti}(\mathrm{IV})$ 很近. 基于以上的讨论, 我们提出了 一个乙烯环氧化及后续开环溶剂解反应生成MME和EG 的反应模型(见图式1) ${ }^{[15]}$.

\section{4. 结论}

采用TPABr-NBA合成体系, 将三价离子 $\left(\mathrm{Al}^{3+}, \mathrm{B}^{3+}\right.$
或 $\mathrm{Fe}^{3+}$ )和 $\mathrm{Ti}^{4+}$ 同时引入到MFI型分子篎的骨架, 制备出 同时具有氧化和酸催化活性的M-TS-1 (M=Al, B或Fe) 分子篮. 通过一系列的表征手段对样品进行了系统的表 征, 结果表明, 三价离子进入了分子篮骨架, 且M-TS-1 依然保持着良好的MFI结构; 三价离子的引入提高了 TS-1的酸强度和酸量. TS-1和M-TS-1酸性强弱的顺序为 TS- $1<$ B-TS- $1<$ Fe-TS-1 < Al-TS- 1 . 通过掺杂不同含量 的三价元素来调配其催化氧化和酸催化活性, 篮选出合 适的双功能钛硅分子篮Al-TS-1 (Si/Al = 252) 和B-TS-1 $(\mathrm{Si} / \mathrm{B}=350)$. 二者在乙烯的选择氧化反应中表现出较高 的催化性能, $\mathrm{H}_{2} \mathrm{O}_{2}$ 的转化率在 $95 \%$ 以上, $\mathrm{H}_{2} \mathrm{O}_{2}$ 的利用率 高于 $90 \%, \mathrm{EG}$ 和MME的总收率可达 $10 \%$ 以上, 与现有工 业上生产EG的收率相当(10\%左右). 最后, 提出了一个 M-TS-1催化乙烯环氧化及其后续开环反应的模型. 